Article

\title{
Sustainable Knowledge Management and Firm Innovativeness: The Contingent Role of Innovative Culture
}

\author{
Abang Azlan Mohamad ${ }^{1, * \mathbb{C}}$, T. Ramayah ${ }^{2,3,4}$ a and May Chiun Lo ${ }^{1}$ \\ 1 Faculty of Economics and Business, Universiti Malaysia Sarawak, Kota Samarahan, \\ Sarawak 94300, Malaysia; mclo@unimas.my \\ 2 School of Management, Universiti Sains Malaysia, Minden, Penang 11800, Malaysia; ramayah@usm.my \\ 3 Internet Innovation Research Center, Newhuadu Business School, Minjiang University, \\ Fuzhou 350108, China \\ 4 Faculty of Accounting and Management, Universiti Tunku Abdul Rahman (UTAR), Sungai Long Campus, \\ Cheras 43000, Malaysia \\ * Correspondence: maazlan@unimas.my
}

Received: 1 August 2020; Accepted: 19 August 2020; Published: 25 August 2020

check for updates

\begin{abstract}
This study presents the moderating effect of innovative culture on the relationship between knowledge management and firm innovativeness. The consequences of organisations that do not practice innovative culture would result in their inability to respond and react effectively to changes in the dynamic nature of the business environment and henceforth unable to achieve superior performance. In attempting to answer the research questions, a total of 202 MSC Malaysia organisations took part in the survey. To assess the developed model, WarpPLS (version 7.0) was applied based on path modelling and then bootstrapping. The results highlighted that three of the four dimensions of knowledge management, namely knowledge acquisition, knowledge application and knowledge protection were positively and significantly related to firm innovativeness. On the other hand, innovative culture was found to moderate the relationships between knowledge acquisition and firm innovativeness; and knowledge application and firm innovativeness.
\end{abstract}

Keywords: knowledge management; innovative culture; firm innovativeness; MSC Malaysia; technology industry; WarpPLS

\section{Introduction}

Organisations perennially pursue ways to stay ahead of their rivals, and one of the ways to be competitive is to equip themselves with knowledge. The importance of knowledge is obvious as it is the antecedence to firm innovativeness. Knowledge management (KM) is regarded as a systematic method in exploiting a firm's knowledge [1] while other scholars [2] consider it as an organised process in administering knowledge assets and processes in the development, dissemination and application of knowledge to obtain organisational goals. Knowledge is considered as a valuable asset that enables organisations to obtain distinctive skills and attain innovation prospects [3,4]. Apart from knowledge, technological competencies act as an important role for organisation in their quests to develop new products and services that propel the organisation into obtaining competitive advantage [5].

As a result of the intense nature of global competition, organisations realised the importance of innovation to ensure their effectiveness, survival and performance [6,7]. It involves the effective use of new ideas [8] and is related to the formation and utilisation of knowledge [5]. Innovation process relies largely on knowledge since knowledge characterises an ambit that is more meaningful than data, 
information and traditional logic [9]. Additionally, previous study [10] proposes the potential of KM in enhancing innovation and improve competitiveness through various KM initiatives.

Organisations that lack the appropriate culture will find sharing of knowledge to be limited and demanding as organisations are made up of employees who provide the necessary knowledge for the organisation to learn and improve. An organisational culture is regarded as an interconnected force that encourages their members to impart values, principles and beliefs of the organisation as these principles and values form employees' future attitudes and characteristics. Furthermore, organisations that focus on innovative culture are highly likely to be internally-focused and highly competitive, as these organisations are expected to embrace novel ideas, processes or products successfully [11].

Despite the importance of KM and the realisation of its significance to organisations, the majority of these KM initiatives stumbled into failures, due to various causes such as the unsuitable adoption of KM strategy, over-reliance on information technology and being unaware of the outcome of KM. On that note, scholars [12] found that the concept of KM is comparatively new in the Malaysian perspective and Malaysian industries trail other countries in adopting KM as some organisations are unsure of the advantages of KM.

Organisations that resist innovation are likely to fail in their business ventures $[13,14]$ and would not be able to develop new and improved products and services that could be translated into profitability. The effects of organisations not practicing innovativeness would be impaired of their ability to respond and react effectively to changes in the dynamic nature of the business environment and lessen the ability of the organisation to achieve superior performance [15]. These organisations will be unable to manufacture their products efficiently, resulting in poor performance [16], failing to achieve superior performance [17] and being incapable of sustaining competitive advantage [18-20].

The significance of knowledge management in predicting firm innovativeness is recognised in the literature; nevertheless, there appears to be a lack of empirical research linking knowledge management, innovative culture and firm innovativeness in a single framework, as these constructs were investigated in isolation. This study attempts to examine the effects of KM, namely, knowledge acquisition, knowledge conversion, knowledge application and knowledge protection, in strengthening firm innovativeness and subsequently the performance of organisations. Additionally, this research endeavours to answer if innovative culture moderates the relationship between KM and firm innovativeness. The present research attempts to explore an in-depth comprehension on the role of innovative culture on the connections between knowledge management and firm innovativeness.

\section{Literature Review}

\subsection{Firm Innovativeness}

Firm innovativeness is regarded as an organisation's capacity to be involved in novelty activities, such as the introduction of new products or services, new procedures or new methods [21]. As such, these innovative companies regularly reintroduce business processes and involve in novel activities that result in the creation of new products, processes, and services [22,23]. Innovativeness is believed to be the catalyst that drives organisations towards competitive dominance [24] and the firm's ability to innovate enables the company to constantly remodel and adapt in dynamic business environment [25]. Additionally, it has also been proven consistently that firm innovativeness is a significant enabler that propels organisations towards better performance [26,27].

\subsection{Knowledge Management}

Knowledge management (KM) refers to identification, production, presentation, distribution and acquisition of knowledge in order to process a standard within an organisation [28]. It covers the process to understand and acquire data, information and knowledge that are vital from internal and external sources to enable organisations make informed decisions. KM is a continuous process that encourages employees to obtain and access information seamlessly that would result in these employees enhancing 
their job performance with the newly acquired knowledge [29]. In this vein [30], grouped knowledge management process into four categories namely knowledge acquisition, knowledge conversion, knowledge application and knowledge protection; these four dimensions are adopted for the purpose of this research.

\subsection{Innovative Culture}

Innovative culture is viewed as a series of values and principles that inspire organisations to be innovative. Moreover, it creates a culture of ingenuity and receptiveness to ideas and responsiveness in decision-making [31]. The connection between innovative culture and innovativeness is accentuated in previous studies [32], who investigated the relationship between organisational culture and innovativeness. Organisations that support innovative behaviours would lead towards innovativeness that are beyond the formal or routine norms. As such, innovative culture is considered as a commanding measure that stimulates the aspiration of the organization towards innovativeness. This is suggested in a recent study that innovative culture enables firms to discover new products, services or processes [33]. To sustain innovative culture, organisations are encouraged create a base for innovation whereby it requires changes to the organisation's operation to foster suitable culture and lead organisations in regular period of changes. An innovative culture that harmonises creativity could inspire employees in establishing a high work standards which in turn enhances the creation of innovative products and procedures [34]. Furthermore, an innovative culture amplifies the magnitude of empowering employees and encouraging them to be creative and enhance their abilities that yield innovative products and services.

\subsection{Hypotheses Development}

This paper examines the notion that effective knowledge management enables an organisation to convert knowledge resources into capabilities: in this case, firm innovativeness. In this study, knowledge management comprises of knowledge acquisition, knowledge conversion, knowledge application and knowledge protection [30]. KM indicates to the identification and utilisation of knowledge in an organisation that enable the organisation to attain competitiveness [35]. Their study highlighted that importance of KM in impacting organisations and pointed to the fact that learning and developmental activities enhances performance.

A past study [36] proposes that creating novel ideas and utilising knowledge in organisations, facilitate organisations to be more innovative, effective and efficient through the formation of internal knowledge mechanisms. Hence, by analysing the concepts of KM and innovativeness, this suggests that these concepts are imperative in supporting organisations with the prospect of achieving competitive advantage. Additionally, it is posited that $\mathrm{KM}$ has the ability to assist organisations make key decisions promptly by providing employees with the right information at the right time [37,38]. Recent studies $[39,40]$ point that KM leads to better innovation performance and plays an important role in enhancing innovativeness in information technology companies.

By implementing KM, innovativeness in organisations will be expanded and the execution of KM would enable organisations to achieve competitive advantage [41]. This suggests that to achieve and sustain competitive advantage, it relies on how the organisations utilise and manage knowledge that are in their possession. Moreover, this underlines that KM influences innovation positively, which implies that organisations should make efforts to create networks and awareness among employees that would ensure KM is continually practiced. This will further enable the acquired knowledge to be applied by employees that would enhance innovation practices in organisations. This paper proposes that KM will impact positively on firm innovativeness. In order for organisations to be innovative, the managers would have to acquire knowledge, whether obtained internally or externally. The more knowledge being acquired, the higher the likelihood that the organisations will be innovative. Thereafter, the acquired knowledge would have to be converted and applied throughout the organisations. Additionally, it is imperative that knowledge residing within the organisation is 
protected as knowledge is regarded as a vital resource. By safeguarding the knowledge, organisations are able to utilise it and be responsive to changes in the market. Organisations that are responsive and agile are most likely to be innovative [42]. Therefore, the hypothesis of this study is: "Knowledge management has positive impact on firm innovativeness". Based on the formulated hypothesis, this study will investigate knowledge management from four perspectives, i.e., knowledge acquisition (H1), knowledge conversion (H2), knowledge application (H3) and knowledge protection (H4); in their relationships with firm innovativeness.

\subsection{The Moderating Effects of Innovative Culture}

Innovative culture has a penchant to encourage the creation of new products and services by embracing innovativeness [43] while fostering members of the organisations to utilise their creativeness in trying out new things and explore original ideas [44]. Innovative culture denotes an inspired, exciting work situation, output oriented, ambitious, risk-taking as well as being a crucial link between knowledge-based assets and innovation [45].

Innovative culture is an intricate set of beliefs, principles, responsibilities and values of the organisation that will have an impact on the firm innovativeness if it is deployed and employed carefully [46]. As such, innovative culture may influence employees to be proactive in utilising complex technology for the development of new products [47]. The embedded culture and value within the organisation further influence the behaviour of employees to practice towards being unique and novel.

Additionally, through innovative culture, knowledge can be easily shared among employees and the sharing will ultimately enhance the creation of new ideas which will lead to better performance [48]. In the same vein, innovative culture may be crucial in linking technological knowledge-based assets and innovation as the approach for using technological resources are the essence in deciding the optimum usage of resources and capabilities of the organisation [49]. It was found recently that innovative culture influences supervisors and employees to accept innovative activities that encourage the organisation to be innovative [50]. Accordingly, the hypothesis is formulated as: "The positive relationship between knowledge management and firm innovativeness will be enhanced when innovative culture is high". Based on the developed hypothesis, this study will investigate the moderating role of innovative culture on the relationships between knowledge management and firm innovativeness from four perspectives of KM, i.e., knowledge acquisition (H5), knowledge conversion (H6), knowledge application (H7) and knowledge protection (H8). Figure 1 depicts the conceptual model of the present study.

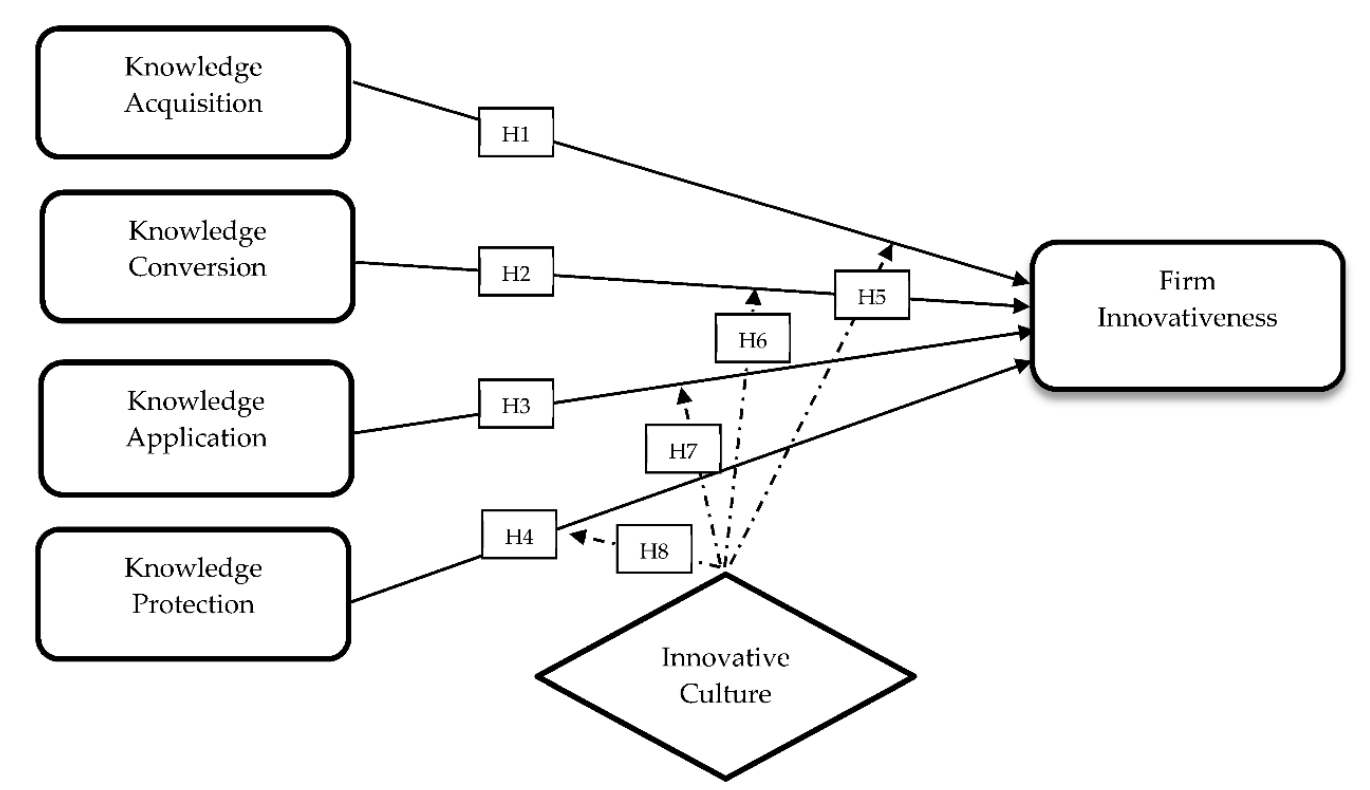

Figure 1. Conceptual Model. 


\section{Methodology}

The population of this study comprised of MSC Malaysia-status companies located in the designated cybercities/cybercentre in Kuala Lumpur and Selangor. The sample size of this research is based on previous studies [51,52] that a sample size of 30 to 500 is sufficient. The data of this study were acquired through a key informant technique whereby the respondents held senior positions in the organisation were selected as key informants. They were deemed to have control and very familiar with their organisations' overall activities, such as innovation, performance and knowledge [53].

As the industry of this study is MSC Malaysia, a list of respondents was derived from Malaysian Digital Economy Corporation (MDEC), an organisation that is responsible for the management of MSC Malaysia. Similar to the Silicon Valley in United States of America and Hsinchu Science and Industrial Park in Taiwan R.O.C., MSC Malaysia is a Malaysian government initiative to springboard Malaysia into the information and knowledge era. As of 2019, there were 2954 MSC Malaysia companies with an annual turnover of 472 billion Ringgit. From the obtained list, $90 \%$ of MSC Malaysia companies were located in the areas of Kuala Lumpur and Selangor.

In total, 1259 survey questionnaires were distributed to Senior Managers of MSC Malaysia companies, of which 218 were returned. Out of the returned questionnaires, 202 were deemed as usable, after being filtered for errors, incompleteness or missing data, thus giving a response rate of $17 \%$. Eight hypotheses were formulated and tested in a field of study. Data were obtained from Chief Executive Officers, General Managers and Senior Managers of these organisations through survey questionnaires. To measure knowledge management, which is represented by knowledge acquisition, knowledge conversion, knowledge application and knowledge protection, 44 items were used [30]. In measuring innovative culture, this study adopted a five-item scale from Ungan [54], while firm innovativeness was adopted from Calantone, Cavusgil and Zhao [55]. All of these items were anchored on a Likert scale of seven points. This study employs WarpPLS 7.0 [56] to measure the model.

\section{Findings}

\subsection{Assessment of the Measurement Model}

In assessing the measurement model, confirmatory factor analysis (CFA) is administered to measure the scale's reliability, discriminant validity and convergent validity. The loadings of all the items are presented in Table 1, which illustrate the loadings being more than 0.5 or $p<0.01$. Moreover, as suggested by Bagozzi and Yi [57], all of the average variance extracted (AVE) surpassed 0.5, while the composite reliability (CR) was above 0.7 [58]. This concludes that convergent validity is realised.

Table 1. Results of the Measurement Model.

\begin{tabular}{clccc}
\hline Construct & \multicolumn{1}{c}{ Measurement Items } & Loadings & AVE & CR \\
\hline $\begin{array}{c}\text { Knowledge } \\
\text { Acquisition [30] }\end{array}$ & $\begin{array}{l}\text { KQ1: My organisation acquires knowledge } \\
\text { about our customers }\end{array}$ & 0.594 & 0.496 & 0.909 \\
\hline & $\begin{array}{l}\text { KQ2: My organisation generates new } \\
\text { knowledge from existing knowledge }\end{array}$ & 0.726 & 0.560 \\
\hline $\begin{array}{l}\text { KQ3: My organisation acquires knowledge } \\
\text { about our suppliers }\end{array}$ & 0.738 & \\
\hline $\begin{array}{l}\text { KQ4: My organisation uses feedback from } \\
\text { projects to improve subsequent projects } \\
\text { KQ5: My organisation distributes knowledge } \\
\text { throughout the organization }\end{array}$ & 0.687 & \\
\hline
\end{tabular}


Table 1. Cont

\begin{tabular}{|c|c|c|c|c|}
\hline Construct & Measurement Items & Loadings & AVE & CR \\
\hline & $\begin{array}{l}\text { KQ6: My organisation exchanges knowledge } \\
\text { with our business partners }\end{array}$ & 0.711 & & \\
\hline & $\begin{array}{l}\text { KQ7: My organisation collaborates with other } \\
\text { organisations }\end{array}$ & 0.669 & & \\
\hline & $\begin{array}{l}\text { KQ8: My organisation acquires knowledge } \\
\text { about new products/services within our } \\
\text { industry }\end{array}$ & 0.605 & & \\
\hline & $\begin{array}{l}\text { KQ9: My organisation acquires knowledge } \\
\text { about competitors within our industry }\end{array}$ & 0.703 & & \\
\hline & $\begin{array}{l}\text { KQ10: My organisation has the ability to } \\
\text { benchmark the organisational performance } \\
\text { compared to the industry }\end{array}$ & 0.654 & & \\
\hline & $\begin{array}{l}\text { KQ11: My organisation identifies best practice } \\
\text { for the company }\end{array}$ & 0.754 & & \\
\hline & $\begin{array}{l}\text { KQ12: My organisation exchanges knowledge } \\
\text { between employees }\end{array}$ & 0.670 & & \\
\hline \multirow[t]{10}{*}{$\begin{array}{l}\text { Knowledge } \\
\text { Conversion [30] }\end{array}$} & $\begin{array}{l}\text { KC1: My organisation converts knowledge into } \\
\text { the design of new products/services }\end{array}$ & 0.587 & 0.507 & 0.911 \\
\hline & $\begin{array}{l}\text { KC2: My organisation converts competitive } \\
\text { intelligence into plans of action }\end{array}$ & 0.711 & & \\
\hline & $\begin{array}{l}\text { KC3: My organisation filters knowledge that } \\
\text { are acquired }\end{array}$ & 0.740 & & \\
\hline & $\begin{array}{l}\text { KC4: My organisation transfers organisational } \\
\text { knowledge to individuals }\end{array}$ & 0.757 & & \\
\hline & $\begin{array}{l}\text { KC5: My organisation absorbs knowledge from } \\
\text { individuals into the organization }\end{array}$ & 0.628 & & \\
\hline & $\begin{array}{l}\text { KC6: My organisation absorbs knowledge from } \\
\text { business partners into the organisation }\end{array}$ & 0.677 & & \\
\hline & $\begin{array}{l}\text { KC7: My organisation distributes knowledge } \\
\text { throughout the organization }\end{array}$ & 0.777 & & \\
\hline & $\begin{array}{l}\text { KC8: My organisation integrates different } \\
\text { sources and types of knowledge }\end{array}$ & 0.805 & & \\
\hline & KC9: My organisation organises knowledge & 0.701 & & \\
\hline & $\begin{array}{l}\text { KC10: My organisation replaces outdated } \\
\text { knowledge }\end{array}$ & 0.710 & & \\
\hline \multirow[t]{5}{*}{$\begin{array}{c}\text { Knowledge } \\
\text { Application [30] }\end{array}$} & $\begin{array}{l}\text { KA1: My organisation applies knowledge } \\
\text { learned from mistakes }\end{array}$ & 0.765 & 0.531 & 0.931 \\
\hline & $\begin{array}{l}\text { KA2: My organisation applies knowledge } \\
\text { learned from experiences }\end{array}$ & 0.797 & & \\
\hline & $\begin{array}{l}\text { KA3: My organisation uses knowledge in } \\
\text { development of new products/services }\end{array}$ & 0.594 & & \\
\hline & $\begin{array}{l}\text { KA4: My organisation uses knowledge to solve } \\
\text { new problems }\end{array}$ & 0.711 & & \\
\hline & $\begin{array}{l}\text { KA5: My organisation matches sources of } \\
\text { knowledge to problems and challenges }\end{array}$ & 0.608 & & \\
\hline
\end{tabular}


Table 1. Cont.

\begin{tabular}{|c|c|c|c|c|}
\hline Construct & Measurement Items & Loadings & AVE & CR \\
\hline & $\begin{array}{l}\text { KA6: My organisation uses knowledge to } \\
\text { improve efficiency }\end{array}$ & 0.800 & & \\
\hline & $\begin{array}{l}\text { KA7: My organisation uses knowledge to } \\
\text { adjust strategic direction }\end{array}$ & 0.703 & & \\
\hline & $\begin{array}{l}\text { KA8: My organisation is able to locate and } \\
\text { apply knowledge to changing competitive } \\
\text { conditions }\end{array}$ & 0.784 & & \\
\hline & $\begin{array}{l}\text { KA9: My organisation makes knowledge } \\
\text { accessible to those who need it }\end{array}$ & 0.755 & & \\
\hline & $\begin{array}{l}\text { KA10: My organisation takes advantage of new } \\
\text { knowledge }\end{array}$ & 0.664 & & \\
\hline & $\begin{array}{l}\text { KA11: My organisation quickly applies } \\
\text { knowledge to critical competitive needs }\end{array}$ & 0.750 & & \\
\hline & $\begin{array}{l}\text { KA12: My organisation quickly links sources of } \\
\text { knowledge in solving problems }\end{array}$ & 0.776 & & \\
\hline \multirow[t]{10}{*}{$\begin{array}{c}\text { Knowledge } \\
\text { Protection [30] }\end{array}$} & $\begin{array}{l}\text { KP1: My organisation protects knowledge } \\
\text { from inappropriate use inside the organization }\end{array}$ & 0.774 & 0.628 & 0.944 \\
\hline & $\begin{array}{l}\text { KP2: My organisation protects knowledge from } \\
\text { inappropriate use outside the organization }\end{array}$ & 0.786 & & \\
\hline & $\begin{array}{l}\text { KP3: My organisation protects knowledge } \\
\text { from theft from within the organisation }\end{array}$ & 0.821 & & \\
\hline & $\begin{array}{l}\text { KP4: My organisation protects knowledge } \\
\text { from theft from outside the organization }\end{array}$ & 0.819 & & \\
\hline & $\begin{array}{l}\text { KP5: My organisation provides incentives to } \\
\text { employees who protect knowledge }\end{array}$ & 0.644 & & \\
\hline & $\begin{array}{l}\text { KP6: My organisation has technology that } \\
\text { restricts access to some sources of knowledge }\end{array}$ & 0.741 & & \\
\hline & $\begin{array}{l}\text { KP7: My organisation has extensive policies } \\
\text { and procedures for protecting trade secrets }\end{array}$ & 0.822 & & \\
\hline & $\begin{array}{l}\text { KP8: My organisation values and protects } \\
\text { knowledge embedded in individuals }\end{array}$ & 0.852 & & \\
\hline & $\begin{array}{l}\text { KP9: My organisation has restricted knowledge } \\
\text { that is clearly identified }\end{array}$ & 0.840 & & \\
\hline & $\begin{array}{l}\text { KP10: My organisation clearly communicates } \\
\text { the importance of protecting knowledge }\end{array}$ & 0.802 & & \\
\hline \multirow{5}{*}{$\begin{array}{l}\text { Innovative } \\
\text { Culture [54] }\end{array}$} & $\begin{array}{l}\text { IC1: The people in my organisation are } \\
\text { encouraged to try new and better ways of } \\
\text { doing their jobs }\end{array}$ & 0.865 & 0.773 & 0.945 \\
\hline & $\begin{array}{l}\text { IC2: Innovation is highly rewarded in our } \\
\text { organisation }\end{array}$ & 0.841 & & \\
\hline & $\begin{array}{l}\text { IC3: Trying new ways of solving problems is } \\
\text { encouraged in our organisation }\end{array}$ & 0.908 & & \\
\hline & $\begin{array}{l}\text { IC4: Our organisation's culture allows people } \\
\text { to be creative }\end{array}$ & 0.897 & & \\
\hline & $\begin{array}{l}\text { IC5: In our organisation, change is viewed as a } \\
\text { positive factor, which brings new opportunities }\end{array}$ & 0.884 & & \\
\hline
\end{tabular}


Table 1. Cont.

\begin{tabular}{|c|c|c|c|c|}
\hline Construct & Measurement Items & Loadings & AVE & $\mathrm{CR}$ \\
\hline \multirow{5}{*}{$\begin{array}{l}\text { Firm } \\
\text { Innovativeness [55] }\end{array}$} & $\begin{array}{l}\text { FI1: Our organisation frequently tries out new } \\
\text { ideas }\end{array}$ & 0.877 & 0.613 & 0.897 \\
\hline & $\begin{array}{l}\text { FI2: Our organisation seeks out new ways to } \\
\text { do things }\end{array}$ & 0.860 & & \\
\hline & $\begin{array}{l}\text { FI3: Our organisation is creative in its methods } \\
\text { of operation }\end{array}$ & 0.848 & & \\
\hline & $\begin{array}{l}\text { FI4: Our organisation is often the first to } \\
\text { market with new products and services }\end{array}$ & 0.842 & & \\
\hline & $\begin{array}{l}\text { FI6: Our new product introduction has } \\
\text { increased over the last } 5 \text { years }\end{array}$ & 0.771 & & \\
\hline
\end{tabular}

Table 2 describes the constructs' discriminant validity. In deciphering the discriminant validity, AVE was square rooted in order to contrast against the intercorrelations of the model's construct as means to confirm discriminant validity [59-61]. The results show that the AVE square root surpassed the correlation against other variables.

Table 2. Discriminant Validity HTMT of Measurement Model.

\begin{tabular}{ccccccc}
\hline Constructs & KQ & KC & KA & KP & FI & IC \\
\hline KQ & - & & & & & \\
KC & 0.753 & - & & & & \\
KA & 0.759 & 0.798 & - & & & \\
KP & 0.571 & 0.564 & 0.622 & - & & \\
FI & 0.489 & 0.435 & 0.493 & 0.508 & - & \\
IC & 0.428 & 0.474 & 0.516 & 0.539 & 0.742 & - \\
\hline
\end{tabular}

Note: $\mathrm{KQ}=$ Knowledge Acquisition, $\mathrm{KC}=$ Knowledge Conversion, $\mathrm{KA}=$ Knowledge Application, $\mathrm{KP}=$ Knowledge Protection, IC = Innovative Culture, FI = Firm Innovativeness. The same in the following tables.

\subsection{Assessment of the Structural Model}

To assess the structural model and test the proposed hypotheses using Partial Least Square (PLS) Structural Equation Modelling (SEM) (PLS-SEM), two criteria should be considered and interpreted: the coefficient of determination $\left(R^{2}\right)$ to measure for the endogenous constructs and the path coefficients $[62,63]$. The path coefficients must be significant; however, the value of $R^{2}$ can vary depending on the research area. In assessing $R^{2}$, the values of $0.19,0.33$ and 0.67 is classified as weak, moderate and substantial respectively [59]. In this research the $\mathrm{R}^{2}$ firm innovativeness is at the level of 0.253 .

\section{Discussion}

The results underline important findings on the linkages within the present study as depicted in Table 3. This research is probably the first to examine the dimensions of knowledge management, innovative culture and firm innovativeness in a framework as most research have studied these constructs in isolation. Previous studies have shown that knowledge acquired from customers, business partners and suppliers may possibly improve an organisation's technological competencies and enhance the development of new products and encourages the shaping of technological capability within the organisation [64]. Extending previous a study by Zhou and Li [65], this research found that knowledge acquisition has a significant and positive relationship with firm innovativeness, thus lending support to $\mathrm{H} 1$. 
Table 3. Summary of Path Coefficient and Hypotheses Testing.

\begin{tabular}{|c|c|c|c|c|c|c|c|c|c|}
\hline Hypothesis & Relationship & Std Beta & Std Error & $\mathrm{t}$-Values & $p$-Value & BCI 95\% LL & BCI 95\% UL & Effect Size $\left(f^{2}\right)$ & Decision \\
\hline H1 & $\mathrm{KQ} \rightarrow \mathrm{FI}$ & 0.196 & 0.068 & $2.892 * *$ & 0.002 & 0.063 & 0.329 & 0.097 & Supported \\
\hline $\mathrm{H} 2$ & $\hat{\mathrm{KC}} \rightarrow \mathrm{FI}$ & -0.008 & 0.070 & -0.120 & 0.452 & -0.146 & 0.129 & 0.004 & Not supported \\
\hline $\mathrm{H} 3$ & $\mathrm{KA} \rightarrow \mathrm{FI}$ & 0.182 & 0.068 & $2.681 * *$ & 0.004 & 0.049 & 0.315 & 0.091 & Supported \\
\hline H5 & $\mathrm{KQ}^{*} \mathrm{IC} \rightarrow \mathrm{FI}$ & 0.116 & 0.069 & $1.687 *$ & 0.047 & -0.019 & 0.251 & 0.018 & Supported \\
\hline H6 & $\mathrm{KC}^{*} \mathrm{IC} \rightarrow \mathrm{FI}$ & 0.072 & 0.069 & 1.040 & 0.150 & -0.064 & 0.208 & 0.012 & Not Supported \\
\hline $\mathrm{H} 7$ & $\mathrm{KA}^{*} \mathrm{IC} \rightarrow \mathrm{FI}$ & 0.230 & 0.069 & $3.408 * *$ & $<0.001$ & 0.098 & 0.362 & 0.039 & Supported \\
\hline
\end{tabular}

The results on $\mathrm{H} 2$ reveal that the relationship between knowledge conversion and innovativeness is non-significant; thus, $\mathrm{H} 2$ is not supported. The findings suggest that knowledge conversion activities do not have any impact on firm innovativeness. One of the ways to improve knowledge conversion that would enhance firm innovativeness is through activities such as face-to-face discussion and learning through observation [66]. One of the reasons for the inconsistencies in the findings could be due to the nature of knowledge conversion itself. Knowledge conversion involves activities undertaken by employees in updating the organisation's old knowledge into new knowledge [38] and since MSC Malaysia companies are technology companies with technology savvy employees, it is highly likely that the employees on their own are keeping abreast with new knowledge in order to be better equipped in performing their jobs. Besides, these employees are also technologically-inclined and they may get the impression that on-the-job conversion process of new knowledge, such as training, may not be necessary.

The findings of this study confirmed that knowledge application enhances firm innovativeness, thus supporting H3. This corresponds with the study by Huang and Li [67] who elucidate that the application of knowledge accelerates the transformation of knowledge into innovativeness. Undoubtedly, the findings of this research further support the work of Obeidat, AlSuradi, Masa'deh and Tarhini [68], who discovered that knowledge application is an important predictor of innovativeness.

The findings reveal that knowledge protection has a significant and positive relationship with firm innovativeness (H4). This is in harmony with a study by Estrada, Faems and de Faria [69] who elucidate that knowledge protection has a significant impact of innovativeness. The results support the study by Jean, Sinkovic and Hiebaum [70], who imply that knowledge protection allows organisations to create a formal communication line through innovative mechanism, such as assigning technological communicative coding on the obligations and duties in the organisations. In the same breath, it is imperative for organisations to create innovation that governs and establishes effective guidelines to protect knowledge and provides employees with innovative and technological system that prevents unauthorised access to knowledge [38].

The results further highlight that innovative culture enhances two of the relationships of knowledge management and firm innovativeness, namely knowledge acquisition and knowledge application, thus supporting $\mathrm{H} 5$ and H7, respectively. The findings correspond with a study by Jim Navare and Lynch [71] where innovative culture was found to drive organisations towards innovativeness, as well as by Wang and Chen [72], who advocated that innovative culture enhances these relationships. The plot of the moderation effect of innovative culture on the relationship knowledge acquisition and firm innovativeness is represented in Figure 2 while moderation effects of innovative culture between knowledge application and firm innovativeness is illustrated in Figure 3. The findings of the present study support the above assertions that innovative culture enhances the positive relationship between knowledge acquisition and firm innovativeness. When organisations practice high level of innovative culture, it increases innovative practices in the organisation [73]. By acquiring knowledge, this will result in a positive impact on firm innovativeness and hence, innovative culture is found to amplify this effect. The results of the present study underline the fact that innovative culture plays a significant impact in enhancing creativity among employees and encourages them to develop the necessary skills that improve innovativeness within the firms. Furthermore, the findings correspond with the study by 
Kfir [74], who found that innovative culture supports the ideation of innovative products and practices in organisations. This indicates that when innovative culture is nurtured by MSC Malaysia firms, employees and the organisations will benefit from it.
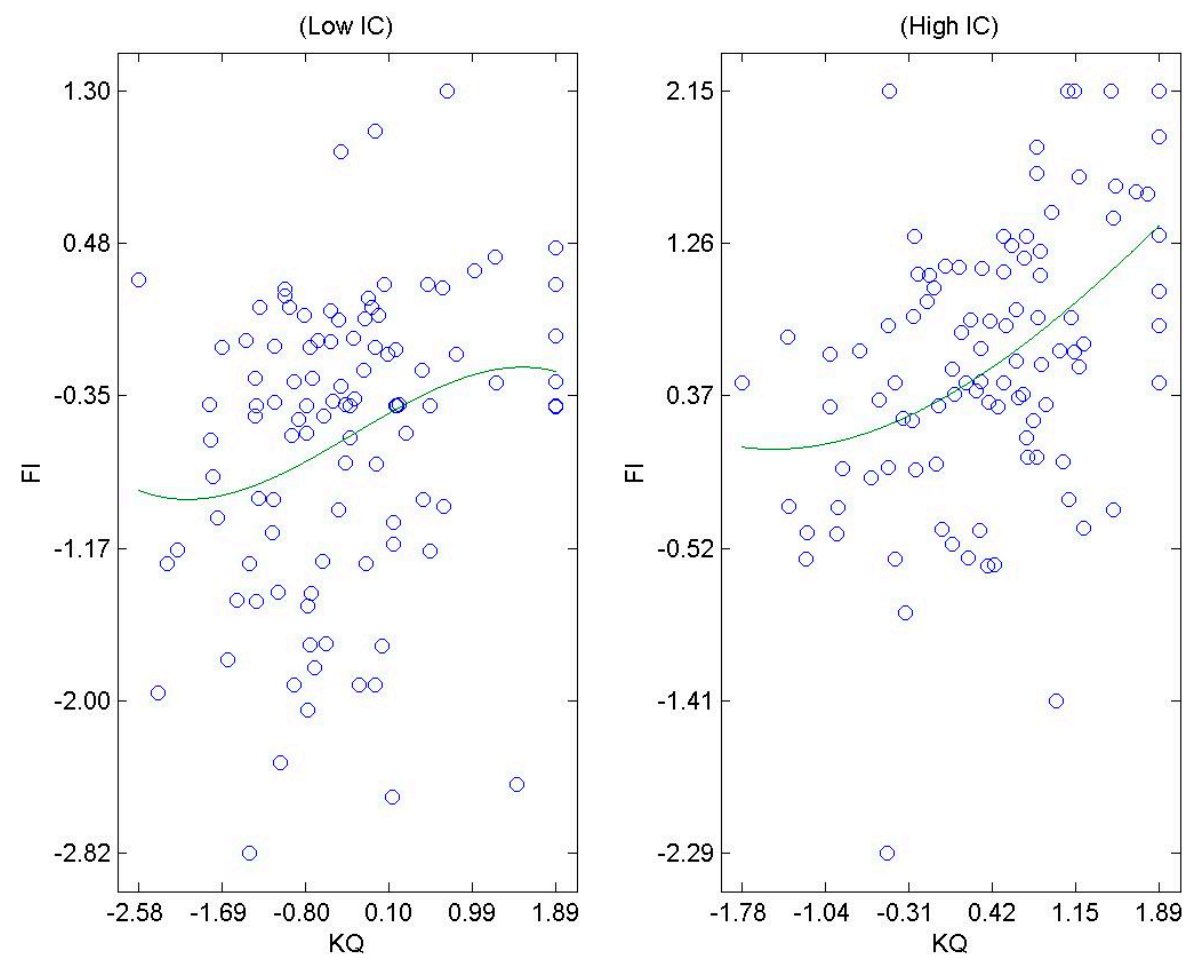

Figure 2. Plots of the moderation effects of innovative culture on the relationship between knowledge acquisition and firm innovativeness.
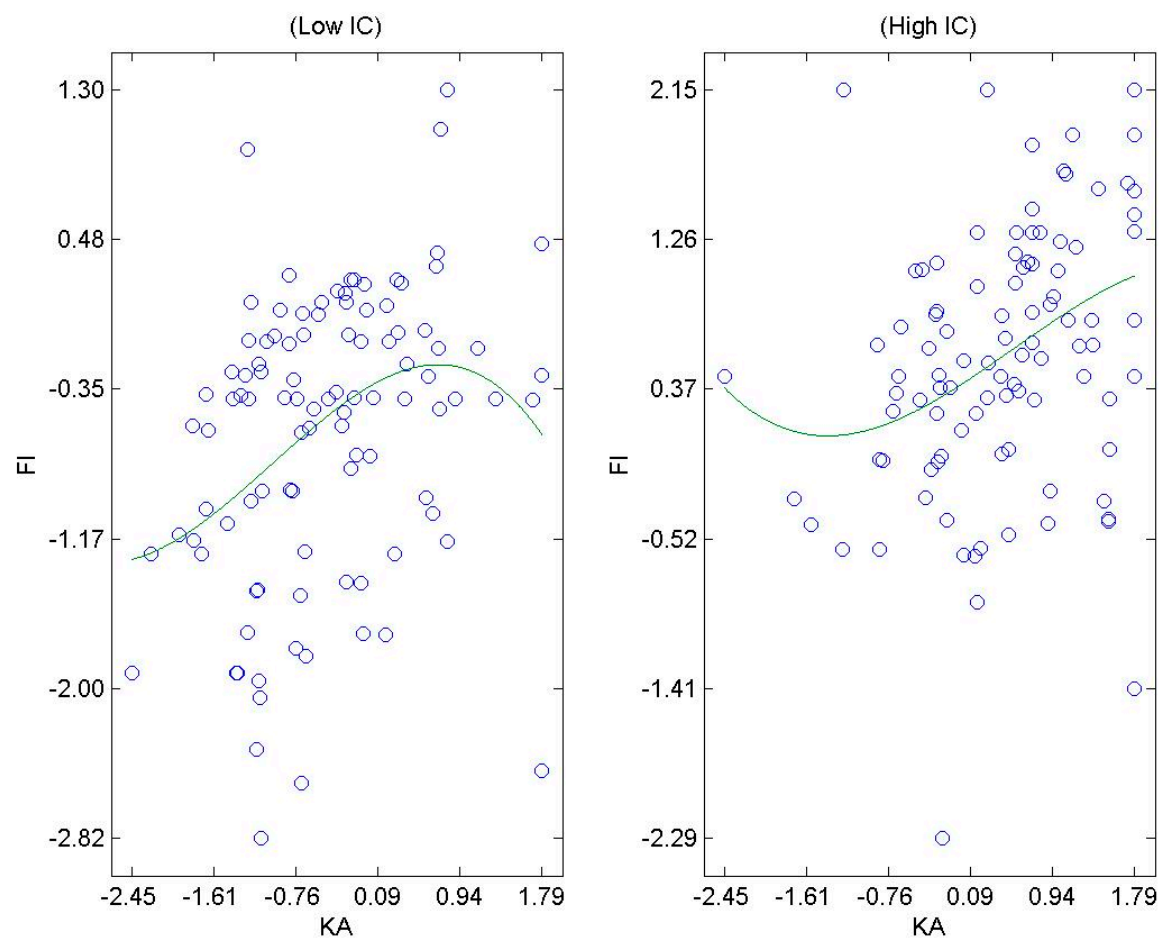

Figure 3. Plots of the moderation effects of innovative culture on the relationship between knowledge application and firm innovativeness. 


\section{Managerial Implications and Conclusions}

The present study offers managers and practitioners the opportunity to further the understanding of resources and capabilities such as knowledge management and firm innovativeness. The results of this research indicate that through innovative culture, knowledge acquisition and knowledge application enhance firm innovativeness. Therefore, it is imperative for MSC Malaysia managers to instil the appropriate culture, in this case, innovative culture, as the present study has shown that it is regarded as the stimulus that spurs organisations to acquire, convert and apply the appropriate knowledge that enhances firm innovativeness. Organisations that have the inclination to innovate will stand a better chance in obtaining superior performance, and hence, it is crucial for organisations to escalate the practice of innovative culture within the organisation in order to set the tone for all employees to be innovative such as in the development of innovative products, processes or ideas. Similarly, the results of the present study infer that innovative culture is conducive in expediting the relationship between knowledge management and firm innovativeness. Therefore, this underlines the fact that to enhance firm innovativeness among MSC Malaysia companies, managers are suggested to apportion resources accordingly based on the findings of this study. As such, it is recommended that MSC Malaysia companies pay greater attention to acquiring and applying knowledge, as well as inculcating an innovative culture, to attain firm innovativeness, which will ultimately lead to better performance.

This research epitomises the theoretical perspective of the investigation into the role of innovative culture in the context of the relationship between knowledge management and firm innovativeness in technology industry. The importance of knowledge management as an antecedence of firm innovativeness is well documented in the literature; however, there appears to be a lack of empirical research on the intermediaries on the linkage between knowledge management and firm innovativeness. This study has enabled an in-depth comprehension on the role of innovative culture on the relationship between knowledge management and firm innovativeness. Therefore, this research has contributed to the growing body of knowledge on the context of knowledge management, innovative culture and firm innovativeness.

\section{Directions for Future Research}

The constraints of this research presented several recommendations for future research to enhance the results of the linkage between knowledge management and firm innovativeness. Firstly, since this study focused solely on MSC Malaysia firms, future studies may include organisations from other sectors, such as banking, transportation or manufacturing, small and medium enterprises (SMEs) or multinational companies that rely heavily on technology.

Moreover, since the number of responses from organisations who participated in this study is rather moderate, i.e., 202 organisations, future studies may incorporate larger samples size that would likely yield a more precise finding. As such, future studies may incorporate organisations who apply knowledge management and innovativeness in various industries, sectors, sizes and types. Future study can be further repeated in other countries to gain a deeper comprehension on the variables of the present study. Another potential study could introduce a mediating variable into the research framework that could support substantial impact on the development of MSC Malaysia.

Author Contributions: Conceptualization, A.A.M., T.R. and M.C.L.; Methodology, A.A.M., T.R. and M.C.L.; Software, A.A.M., T.R. and M.C.L.; Validation, A.A.M., T.R. and M.C.L.; Formal analysis, A.A.M., T.R. and M.C.L.; Writing—original draft preparation, A.A.M.; Writing—review and editing, A.A.M., T.R. and M.C.L.; All authors have read and agreed to the published version of the manuscript.

Funding: This research received funding from Universiti Malaysia Sarawak (UNIMAS) and Sarawak Multimedia Authority (SMA)

Conflicts of Interest: The authors declare no conflict of interest. 


\section{References}

1. Abubakar, A.M.; Elrehail, H.; Alatailat, M.A.; Elçi, A. Knowledge management, decision-making style and organizational performance. J. Innov. Knowl. 2019, 4, 104-114. [CrossRef]

2. An, X.; Deng, H.; Chao, L.; Bai, W. Knowledge management in supporting collaborative innovation community capacity building. J. Knowl. Manag. 2014, 18, 574-590. [CrossRef]

3. Chen, C.J.; Huang, J.W.; Hsiao, Y.C. Knowledge management and innovativeness: The role of organizational climate and structure. Int. J. Manpow. 2010, 31, 848-870. [CrossRef]

4. Grant, R.M. Toward a knowledge-based theory of the firm. Strateg. Manag. J. 1996, 17, 109-122. [CrossRef]

5. Alegre, J.; Sengupta, K.; Lapiedra, R. Knowledge management and innovation performance in a high-tech SMEs industry. Int. Small Bus. J. 2013, 31, 454-470. [CrossRef]

6. Kyrgidou, L.P.; Spyropoulou, S. Drivers and performance outcomes of innovativeness: An empirical study. Br. J. Manag. 2013, 24, 281-298. [CrossRef]

7. Tajeddini, K. The impact of learning orientation on NSD and hotel performance. Educ. Bus. Soc. Contemp. Middle East. Issues 2009, 2, 262-275. [CrossRef]

8. Amabile, T.M.; Conti, R.; Coon, H.; Lazenby, J.; Herron, M. Assessing the work environment for creativity. Acad. Manag. J. 1996, 39, 1154-1184.

9. Nonaka, I.; Takeuchi, H. The Knowledge-Creating Company: How Japanese Companies Create the Dynamics of Innovation; Oxford University Press: Oxford, UK, 1995.

10. Gloet, M.; Samson, D. Knowledge management and systematic innovation capability. Int. J. Knowl. Manag. 2016, 12, 54-72. [CrossRef]

11. Ali, M.; Park, K. The mediating role of an innovative culture in the relationship between absorptive capacity and technical and non-technical innovation. J. Bus. Res. 2016, 69, 1669-1675. [CrossRef]

12. Jayasingam, S.; Ansari, M.A.; Ramayah, T.; Jantan, M. Knowledge management practices and performance: Are they truly linked? Knowl. Manag. Res. Pract. 2013, 11, 255-264. [CrossRef]

13. Ho, L.A. What affects organizational performance? The linking of learning and knowledge management. Ind. Manag. Data Syst. 2008, 108, 1234-1254. [CrossRef]

14. Leavy, B. The concept of learning in the strategy field: Review and outlook. Manag. Learn. 1998, 29, 447-466. [CrossRef]

15. Montes, F.J.L.; Moreno, A.R.; Fernández, L.M.M. Assessing the organizational climate and contractual relationship for perceptions of support for innovation. Int. J. Manpow. 2004, 25, 167-180. [CrossRef]

16. Gunday, G.; Ulusoy, G.; Kilic, K.; Alpkan, L. Effects of innovation types on firm performance. Int. J. Prod. Econ. 2011, 133, 662-676. [CrossRef]

17. Rahman, M.; Aziz, S.; Hughes, M. The product-market performance benefits of environmental policy: Why customer awareness and firm innovativeness matter. Bus. Strateg. Environ. 2020. [CrossRef]

18. Drucker, P. Innovation and Entrepreneurship; Harper \& Row: New York, NY, USA, 1985.

19. Hitt, M.A.; Ireland, R.D.; Camp, S.M.; Sexton, D.L. Strategic entrepreneurship: Entrepreneurial strategies for wealth creation. Strateg. Manag. J. 2001, 22, 479-491. [CrossRef]

20. Kuratko, D.F.; Ireland, R.D.; Covin, J.G.; Hornsby, J.S. A model of middle-level managers' entrepreneurial behavior. Entrepr. Theory Pract. 2005, 29, 699-716. [CrossRef]

21. Alegre, J.; Pasamar, S. Firm innovativeness and work-life balance. Technol. Anal. Strateg. Manag. 2018, 30, 421-433. [CrossRef]

22. Dibrell, C.; Fairclough, S.; Davis, P.S. The impact of external and internal entrainment on firm innovativeness: A test of moderation. J. Bus. Res. 2015, 68, 19-26. [CrossRef]

23. Hurley, R.F.; Hult, G.T.M. Innovation, market orientation, and organizational learning: An integration and empirical examination. J. Mark. 1998, 62, 42-54. [CrossRef]

24. Zehir, C.; Balak, D. Market dynamism and firm performance relation: The mediating effects of positive environment conditions and firm innovativeness. EMAJ Emerg. Mark. J. 2018, 8, 45-51. [CrossRef]

25. Rajapathirana, R.P.J.; Hui, Y. Relationship between innovation capability, innovation type, and firm performance. J. Innov. Knowl. 2018, 3, 44-55. [CrossRef]

26. Craig, J.B.; Dibrell, C.; Garrett, R. Examining relationships among family influence, family culture, flexible planning systems, innovativeness and firm performance. J. Fam. Bus. Strateg. 2014, 5, 229-238. [CrossRef] 
27. Tsai, K.H.; Yang, S.Y. Firm innovativeness and business performance: The joint moderating effects of market turbulence and competition. Ind. Mark. Manag. 2013, 42, 1279-1294. [CrossRef]

28. Ramdani, D.M.; Hadijah, H.S. The influence of profit and cash flow to predict financial. Dinas. Int. J. Manag. Sci. 2020, 1, 191-203. [CrossRef]

29. Mahdi, O.R.; Nassar, I.A.; Almsafir, M.K. Knowledge management processes and sustainable competitive advantage: An empirical examination in private universities. J. Bus. Res. 2019, 94, 320-334. [CrossRef]

30. Gold, A.H.; Malhotra, A.; Segars, A.H. Knowledge management: An organizational capabilities perspective. J. Manag. Inform. Syst. 2001, 18, 185-214. [CrossRef]

31. Toaldo, A.M.M.; Didonet, S.R.; Luce, F.B. The influence of innovative organizational culture on marketing strategy formulation and results. Lat. Am. Bus. Rev. 2013, 14, 251-269. [CrossRef]

32. Hogan, S.J.; Coote, L.V. Organizational Culture, Innovation, and Performance: A Test of Schein's Model. J. Bus. Res. 2014, 67, 1609-1621. [CrossRef]

33. Bendak, S.; Shikhli, A.M.; Abdel-Razek, R.H. How changing organizational culture can enhance innovation? Development of the innovative culture enhancement framework. Cogent Bus. Manag. 2020, 7. [CrossRef]

34. Khan, S.K.; Memon, M.A.; Ramayah, T. Leadership and innovative culture influence on organisational citizenship behaviour and affective commitment: The mediating role of interactional justice. Int. J. Bus. Soc. 2018, 19, 725-747.

35. Kianto, A.; Vanhala, M.; Heilmann, P. The impact of knowledge management on job satisfaction. J. Knowl. Manag. 2016, 20, 621-636. [CrossRef]

36. Santoro, G.; Vrontis, D.; Thrassou, A.; Dezi, L. The Internet of things: Building a knowledge management system for open innovation and knowledge management capacity. Technol. Forecast. Soc. Chang. 2018, 136, 347-354. [CrossRef]

37. Imran, M.K. Impact of knowledge management infrastructure on organizational performance with moderating role of KM performance: An empirical study on banking sector of Pakistan. Inf. Knowl. Manag. 2014, 4, 85-99.

38. Tseng, S.M. The impact of knowledge management capabilities and supplier relationship management on corporate performance. Int. J. Prod. Econ. 2014, 154, 39-47. [CrossRef]

39. Al Ahbabi, S.A.; Singh, S.K.; Balasubramanian, S.; Gaur, S.S. Employee perception of impact of knowledge management processes on public sector performance. J. Knowl. Manag. 2019, 23, 351-373. [CrossRef]

40. Butt, M.A.; Nawaz, F.; Hussain, S.; Sousa, M.J.; Wang, M.; Sumbal, M.S.; Shujahat, M. Individual knowledge management engagement, knowledge-worker productivity, and innovation performance in knowledge-based organizations: The implications for knowledge processes and knowledge-based systems. Comput. Math. Organ. Theory 2019, 25, 336-356. [CrossRef]

41. Ngoc-Tan, N.; Gregar, A. Impacts of knowledge management on innovations in higher education institutions: An empirical evidence from Vietnam. Econ. Soc. 2018, 11, 301-320. [CrossRef]

42. Darroch, J. Knowledge management, innovation and firm performance. J. Knowl. Manag. 2005, 9, 101-115. [CrossRef]

43. Zafar, H.; Mehmood, K.K. Innovation as a mediator between innovative culture, transformational leadership, knowledge management, learning orientation, and performance. Innovation 2019, 17, 149-164. [CrossRef]

44. Ghasemzadeh, P.; Nazari, J.A. Moderating role of innovation culture in the relationship between organizational learning and innovation performance. Learn. Organ. 2018, 26, 289-303. [CrossRef]

45. Khan, S.N.; Hussain, R.I.; Ur-Rehman, S.; Maqbool, M.Q.; Engku Ali, E.I.; Numan, M. The mediating role of innovation between corporate governance and organizational performance: Moderating role of innovative culture in Pakistan textile sector. Cogent Bus. Manag. 2019, 6. [CrossRef]

46. Bedi, H.S. Firm level innovativeness: Antecedents and consequences. Envis. Int. J. Commer. Manag. 2016, 10, 68-76.

47. Gatignon, H.; Xuereb, J.M. Strategic orientation of the firm and new product performance. J. Mark. Res. 1997, 34,77-90. [CrossRef]

48. Halim, H.A.; Ahmad, N.H.; Ramayah, T.; Hanifah, H.; Taghizadeh, S.K.; Mohamad, M.N. Towards an Innovation Culture: Enhancing Innovative Performance of Malaysian SMEs. Acad. J. Interdiscipl. Stud. 2015, 4, 85. [CrossRef] 
49. Martín-de Castro, G.; Delgado-Verde, M.; Navas-López, J.E.; Cruz-González, J. The moderating role of innovation culture in the relationship between knowledge assets and product innovation. Technol. Forecast. Soc. Change 2013, 80, 351-363. [CrossRef]

50. Kalyar, M.N.; Shafique, I.; Ahmad, B. Effect of innovativeness on supply chain integration and performance: Investigating the moderating role of environmental uncertainty. Int. J. Emerg. Mark. 2019, 15, 362-386. [CrossRef]

51. Sekaran, U.S. Research Methods for Business: A Skill-Building Approach, 3rd ed.; John Wiley \& Sons: New York, NY, USA, 2000.

52. Roscoe, J.T. Fundamental Research Statistics for the Behavioural Sciences, 2nd ed.; Thomson Learning: London, UK, 1975.

53. Hambrick, D.C. Environment, Strategy, and Power within Top Management Teams. Adm. Sci. Q. 1981, 26, 253-275. [CrossRef]

54. Ungan, M.C. Manufacturing best practices: Implementation success factors and performance. J. Manufact. Technol. Manag. 2007, 18, 333-348. [CrossRef]

55. Calantone, R.J.; Cavusgil, S.T.; Zhao, Y. Learning orientation, firm innovation capability, and firm performance. Ind. Mark. Manag. 2002, 31, 515-524. [CrossRef]

56. Kock, N. Full latent growth and its use in PLS-SEM: Testing moderating relationships. Data Anal. Perspect. J. 2020, 1, 1-5.

57. Bagozzi, R.P.; Yi, Y. On the evaluation of structural equation models. J. Acad. Mark. Sci. 1988, 16, $323-359$. [CrossRef]

58. Gefen, D.; Straub, D.; Boudreau, M.C. Structural equation modeling and regression: Guidelines for research practice. Communications of the association for information systems. Commun. Assoc. Inf. Syst. 2000, 4, 7.

59. Chin, W.W. Commentary issues and opinion on structural equation modeling. MIS Quart. 1998, 22, 7-16.

60. Chin, W.W. The partial least squares approach to structural equation modeling. Mod. Methods Bus. Res. 1998, 295, 295-336.

61. Fornell, C.; Larcker, D.F. Evaluating structural equation models with unobservable variables and measurement error. J. Mark. Res. 1981, 18, 39-50. [CrossRef]

62. Chin, W.W. How to write up and report PLS analyses. In Handbook of Partial Least Squares; Vinzi, V.E., Chin, W.W., Henseler, J., Wang, H., Eds.; Springer: Berlin/Heidelberg, Germany, 2010; pp. 171-193. [CrossRef]

63. Hair, J.F.; Ringle, C.M.; Sarstedt, M. PLS-SEM: Indeed a Silver Bullet. J. Mark. Theory Pract. 2011, 19, $139-152$. [CrossRef]

64. Zhou, K.Z.; Zhang, Q.; Sheng, S.; Xie, E.; Bao, Y. Are relational ties always good for knowledge acquisition? Buyer-supplier exchanges in China. J. Oper. Manag. 2014, 32, 88-98. [CrossRef]

65. Zhou, K.Z.; Li, C.B. How knowledge affects radical innovation: Knowledge base, market knowledge acquisition, and internal knowledge sharing. Strateg. Manag. J. 2012, 33, 1090-1102. [CrossRef]

66. Masrek, M.N.; Yusof, N.I.; Noordin, S.A.; Anwar, N. The relationship between knowledge conversion abilities and academic performance. In International Conference on Information Society (i-Society 2014); Elsevier: London, UK, 2014; pp. 128-133. [CrossRef]

67. Huang, J.W.; Li, Y.H. The mediating effect of knowledge management on social interaction and innovation performance. Int. J. Manpow. 2009, 30, 285-301. [CrossRef]

68. Obeidat, B.Y.; Al-Suradi, M.M.; Masa'deh, R.; Tarhini, A. The impact of knowledge management on innovation. Manag. Res. Rev. 2016, 39, 1214-1238. [CrossRef]

69. Estrada, I.; Faems, D.; de Faria, P. Coopetition and product innovation performance: The role of internal knowledge sharing mechanisms and formal knowledge protection mechanisms. Ind. Mark. Manag. 2016, 53, 56-65. [CrossRef]

70. Jean, R.J.; Sinkovics, R.R.; Hiebaum, T.P. The effects of supplier involvement and knowledge protection on product innovation in customer-supplier relationships: A study of global automotive suppliers in China. J. Product Innov. Manag. 2014, 31, 98-113. [CrossRef]

71. Jin, Z.; Navare, J.; Lynch, R. The relationship between innovation culture and innovation outcomes: Exploring the effects of sustainability orientation and firm size. $R$ D Manag. 2019, 49, 607-623. [CrossRef]

72. Wang, T.C.; Chen, M.-F. Perceiving organisational culture influence on knowledge management performance. Sci. J. Bus. Manag. 2017, 5, 96. [CrossRef] 
73. Nanath, K.; Pillai, R.R. Information Systems Flexibility for Green Technologies. In Organisational Flexibility and Competitiveness; Nandakumar, M.K., Jharkharia, S., Nair, A.S., Eds.; Springer: New Delhi, India, 2014; pp. 181-195.

74. Kfir, R. A Framework, Process and Tool for Managing Technology-based Assets. R D Manag. 2000, 30, 297-304. [CrossRef] 